\title{
Ettringite formation in historic bath brick-lime plasters
}

\author{
Hasan Böke ${ }^{\mathrm{a}, *}$, Sedat Akkurt ${ }^{\mathrm{b}, \mathrm{c}}$ \\ a Architectural Restoration Department, Izmir Institute of Technology, 35430 Izmir, Turkey \\ ${ }^{\mathrm{b}}$ Mechanical Engineering Department, Izmir Institute of Technology, 35430 Izmir, Turkey \\ ${ }^{\mathrm{c}}$ Center for Materials Research, Izmir Institute of Technology, 35430 Izmir, Turkey
}

Received 2 July 2002; accepted 7 March 2003

\begin{abstract}
Two types of historic hydraulic brick-lime plasters from a selected Ottoman bath are examined to characterize their technology and the appropriateness of their use in bath. The first type of plaster is original and structurally sound, while the historic repair plaster is the second type and is found to have deteriorated despite being exposed to the same environment. This difference is investigated by comparing their raw material compositions and the pozzolanic activities of the brick powders used in the plasters. Although these results showed no significant differences, ettringite crystals are detected in the historic repair ones by XRD, FTIR, and SEM-EDS analysis. The repair plaster may have lost its integrity owing to the expansion generated by the growth of ettringite crystals in the plaster. In this study, the ettringite formation is discussed in relation to hydration reaction products of lime-brick plasters, possible sources of gypsum, and the climatic conditions of historic bath building.
\end{abstract}

(C) 2003 Elsevier Ltd. All rights reserved.

Keywords: Ettringite; Gypsum; Degradation; Humidity; Historic brick-lime plaster

\section{Introduction}

Brick-lime mortars and plasters have been used since ancient times due to their hydraulic properties. They are known as Horasan in Turkey [1], Surkhi in India [2], Homra in Arabic countries [3] and Cocciopesto by Romans [4]. Prior to the advent of Portland cement, this type of mortars and plasters were successfully used in historical constructions owing to their desirable characteristics as good cohesion, low porosity and high mechanical properties. They are composed of a mixture of pozzolanic brick powder fragments and lime that may be added either in the form of slaked lime or quicklime. Gypsum was often added into lime as an additive to provide early strength of historic mortars and plasters [5-7].

The brick powder mixed with lime must be fired at low temperature (less than $900{ }^{\circ} \mathrm{C}$ ) to develop desired level of pozzolanacity that is derived from the amorphous structure

* Corresponding author. Tel.: +90-232-498-7035; fax: +90-232-4987012.

E-mail address: hasanboke@iyte.edu.tr (H. Böke). obtained from the decomposition of clay minerals [8,9]. Brick fragments are not just inert filler in the mortars and plasters, but they contribute to strength development through reaction with lime followed by formation of calcium aluminum hydrate and calcium silicate hydrate compounds. This reaction is also known as pozzolanic reaction and is more favorable under relatively high-humidity and high-temperature environments [10].

Ettringite $\left(3 \mathrm{CaO} \cdot \mathrm{Al}_{2} \mathrm{O}_{3} \cdot 3 \mathrm{CaSO}_{4} \cdot 32 \mathrm{H}_{2} \mathrm{O}\right)$ may form in the hydraulic historic mortars and plasters by reaction of gypsum and calcium aluminum hydrates in a moist condition [11]. It is not desirable for historic lime mortars and plasters because it may lead to expansion forces during its growth. In recent years, the possibility of ettringite formation in historic hydraulic mortars or plasters due to air pollution effect has been pointed out [12, 13]. However, in these studies, ettringite formation in historical mortars and plasters was not actually observed. The observations were only limited to modern repair plasters.

In this study, Horasan plaster samples taken from a historic Ottoman bath in Edirne (Saray Bath), Turkey were examined. As opposed to the original historic 
Table 1

Acid soluble/brick ratios of plasters, the particle size distribution (PSD) of brick powders, and their pozzolanic activities

\begin{tabular}{|c|c|c|c|c|c|c|c|c|}
\hline \multirow[t]{2}{*}{ Sample } & \multirow{2}{*}{$\begin{array}{l}\text { Pozzolanic } \\
\text { activity }^{\mathrm{a}}\end{array}$} & \multirow{2}{*}{$\begin{array}{l}\% \text { Acid } \\
\text { soluble }\end{array}$} & \multirow{2}{*}{$\begin{array}{l}\% \\
\text { Brick }\end{array}$} & \multicolumn{5}{|c|}{ PSD of brick powder brick ( $\%$ on micrometer class size) } \\
\hline & & & & $>1000$ & $>500$ & $>250$ & $>125$ & $<125$ \\
\hline Type 1-b & 5.6 & 49.1 & 50.9 & 22.4 & 16.2 & 16.0 & 17.6 & 27.8 \\
\hline Type 1-t & 3.9 & 73.4 & 26.6 & - & - & - & - & 100.0 \\
\hline Type 2 & 5.4 & 53.5 & 46.5 & 18.6 & 19.3 & 21.0 & 19.1 & 22.1 \\
\hline
\end{tabular}

a Pozzolanic activity measured in units of $\Delta \mathrm{EC}$ in $\mathrm{mS} / \mathrm{cm}$.

plasters, the historic repair plasters were swollen, spalled, and deteriorated. Ettringite crystals were identified to be the main cause of the weakness of this plaster. The wrong use of gypsum as an early strength-developing additive in these plasters is suspected to be the reason for ettringite formation.

\section{Materials and method}

Horasan plaster samples are collected from the interior warmth walls of an Ottoman period bath constructed in 1375 in Edirne, Turkey. It was repaired in 1565 during the construction of Selimiye Mosque and once more in the 18th century. It was partially demolished in the war (1920) and has never been used as a bath since that time [14]. A large area of the plaster on the wall remained original (type 1), while other areas are found to be subjected to repair work (type 2). The original type 1 plaster is composed of two layers: type 1 bottom (1-b) and type 1 top (1-t). Sample coded as 1-b is closer to the interior wall and 1-t is on top of it exposed to the bath atmosphere. Both layers of type 1 plaster are structurally sound, while the type 2 is a historic repair layer that was applied in a later period and suffered from significant loss of cohesion and structural integrity. On top of both type 1 and type 2, there is a white surface deposit (WSD) that strongly bonds to the plaster and varies in thickness.

A reflected light optical microscope (Nikon L150) is used in cross-polars to examine the general microstructural features at low magnification. A stereomicroscope is used to separate crystals (ettringite) that are present in type 2 plaster samples.

The proportions of carbonated lime and brick powder and the particle size distribution of the latter are determined by dissolving the former in dilute hydrochloric acid, followed by filtering, drying, and sieving of bricks [15]. Pozzolanic activities of the brick powder (less than 45 $\mu \mathrm{m})$ were determined by mixing them into saturated calcium hydroxide solution and by measuring the differences in electrical conductivity [16].

Mineralogical composition of the plaster matrix, which contained both binder and brick powder, separated brick powder from matrix, WSD, and crystals found in type 2 are analyzed by using Philips X-Pert X-ray diffraction (XRD) and a Mattson 1000 FTIR spectrometer.
A Philips XL30-SFEG scanning electron microscope (SEM) coupled with EDS (EDAX) is used to investigate the microstructure of plasters and semiquantitative chemical analysis of the deposited layers (WSD) on plasters and crystals found in repair one.

\section{Results}

In this section, the general characteristics of plasters, amount of acid-soluble part of plasters, size distribution of brick powder and their pozzolanic activities, mineralogical analysis, and microstructural study results are presented.

\subsection{General characteristics}

Optical microscope analysis of both plaster samples at low magnification $(50 \times)$ revealed the following general features:

- both plasters contain a white layer of deposit (WSD) on their surfaces

- type 1 is a relatively denser, stronger plaster with a characteristic two-layer structure. The top layer $(1.5-2$ $\mathrm{mm}$ thick) has a red color, while the bottom more porous layer $(10 \mathrm{~mm})$ has a lighter shade of pink color

- type 2 is more porous with only one layer $(6-10 \mathrm{~mm})$

- in all plaster layers, brick powder fragments tightly embedded in a lime-based binder matrix is observed

- in type 2, fibrillar crystals with a hexagonal cross-section are optically observed in isolated pockets.

Table 2

XRD analyses of samples

\begin{tabular}{lllllll}
\hline Sample & $\mathrm{C}^{\mathrm{a}}$ & $\mathrm{Q}$ & $\mathrm{F}$ & $\mathrm{H}$ & Ho & AP \\
\hline Type 1-b & +++ & + & - & - & - & - \\
Type 1-t & +++ & + & - & ++ & - & - \\
Type 2 & +++ & + & - & - & - & - \\
Type 1-b brick powder & - & +++ & ++ & - & - & + \\
Type 1-t brick powder & - & + & + & +++ & - & + \\
Type 2 brick powder & - & +++ & + & - & + & + \\
White surface deposit & +++ & - & - & - & - & - \\
\hline
\end{tabular}

${ }^{a}$ C: calcite, F: feldspar, Q: quartz, H: hematite, Ho: hornblende, AP: amorphous phase. 


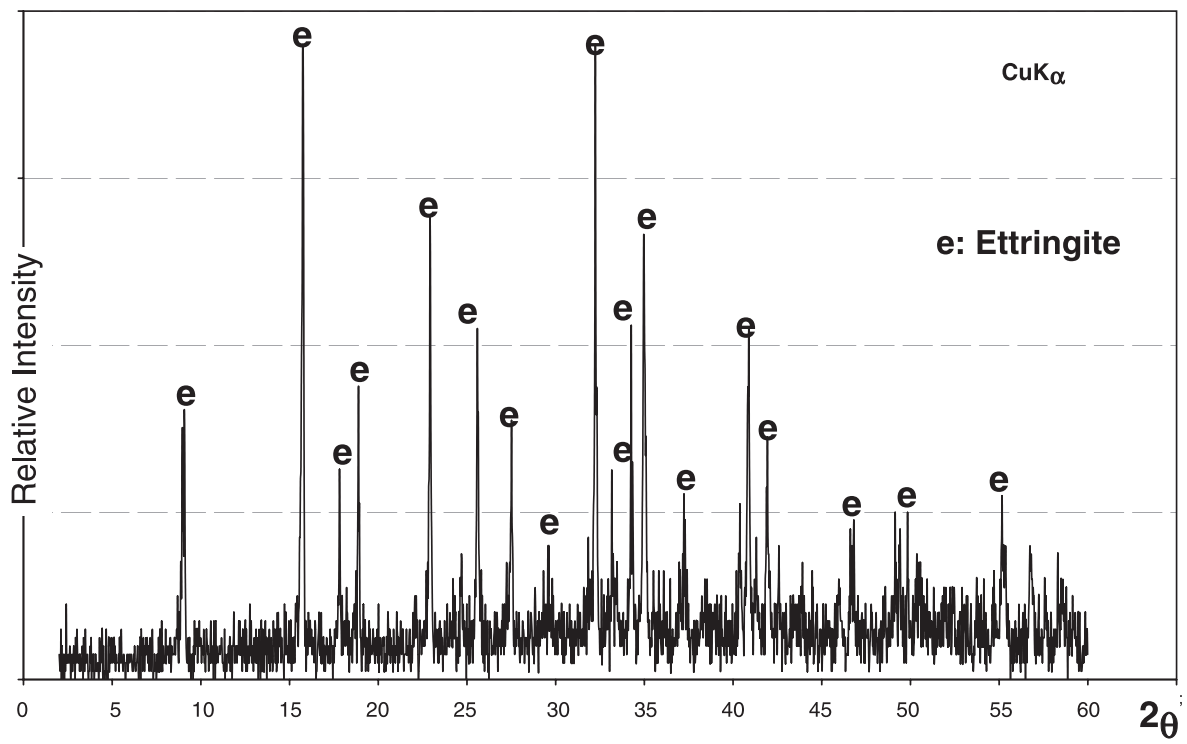

Fig. 1. XRD pattern of ettringite crystals (e) that are hand-separated from the type 2 plaster samples.

3.2. Amount of acid-soluble part of plasters, size distribution of brick powder, and their pozzolanic activities

The amounts of carbonated lime and hydration products such as calcium silicate hydrates are determined by dissolving the plaster in dilute $\mathrm{HCl}$ (Table 1). The undissolved residue is predominantly composed of brick powder. The amounts of brick powder and their particle size distribution are nearly the same in type 1-b and type 2 plasters (Table 1). A high amount of acid-soluble part is indicated in type 1-t. The particle size of brick powder used in this layer is less than $125 \mu \mathrm{m}$. The pozzolanic activities of bricks used in types 1-b and 2 are nearly the same (Table 1).

\subsection{Determination of mineralogical composition}

Results of XRD analysis of both plaster samples, their separated brick powders, and the deposits on plaster surfaces (WSD) are given in Table 2. In the XRD patterns of type 1-b, type 1-t, and type 2, strong peaks of calcite and weaker peaks of quartz are present. Type 1-t also has

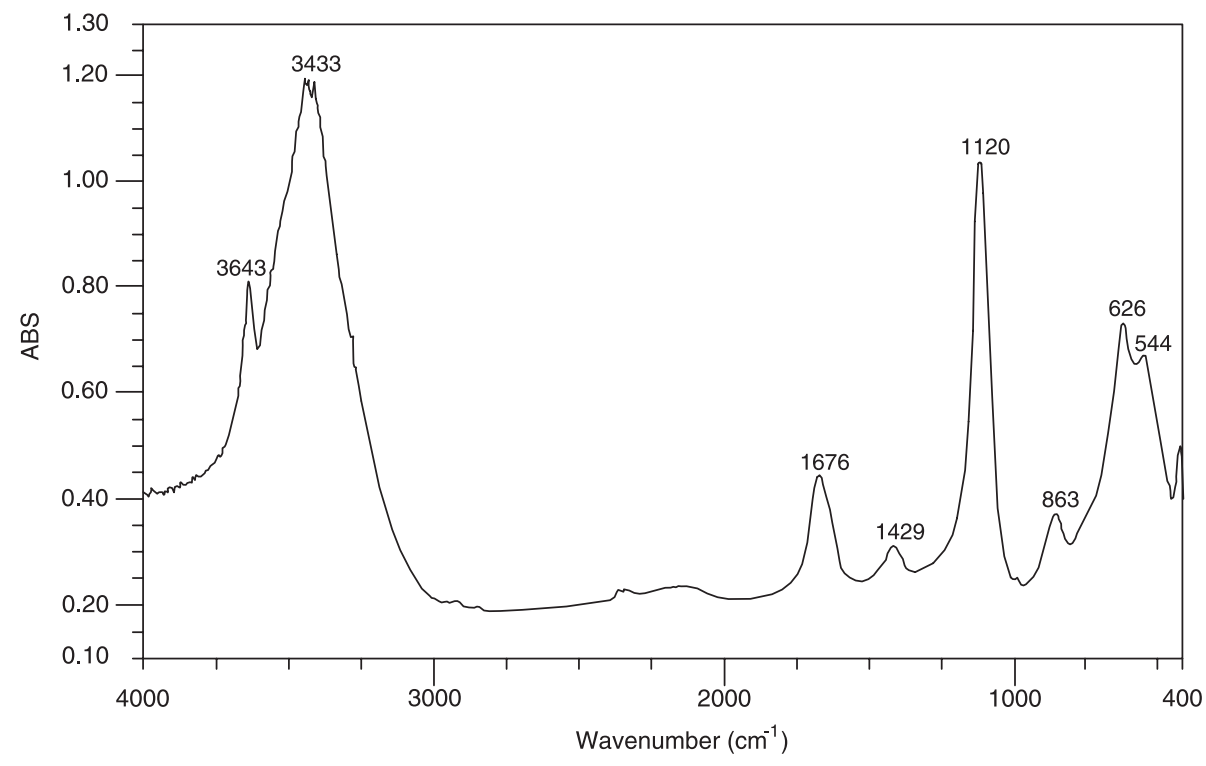

Fig. 2. FTIR spectra of the same separated ettringite crystals as in Fig. 1. 


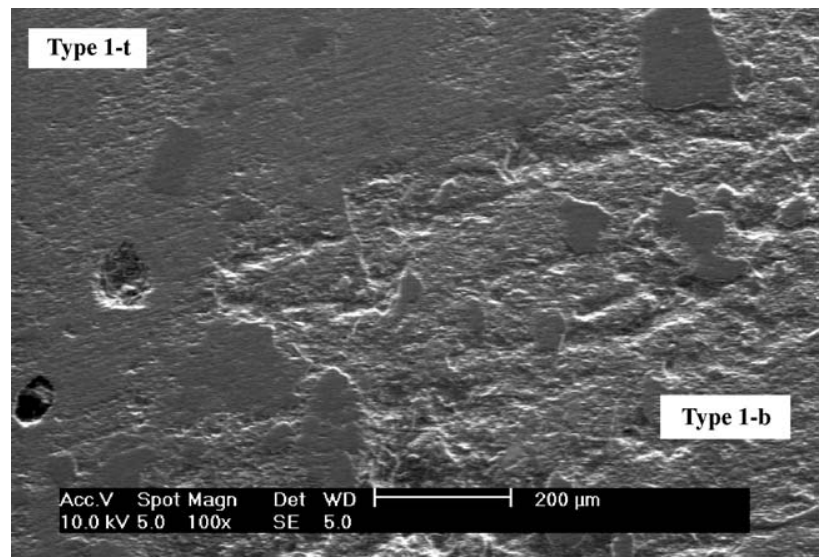

Fig. 3. Secondary electron image (SE) of the top (type 1-t) and bottom (type 1-b) layers of type 1 plaster.

strong hematite peaks. The separated brick powders taken from type $1-b$, type $1-t$, and type 2 have quartz and feldspar as the main constituents in addition to some amorphous phase. The diffuse band with a slight increase in intensity on X-ray spectrum between $20-30^{\circ}$ is characteristic of this amorphous phase. Type 1-t also contains a high amount of hematite. Type 2 contains weak peaks of hornblende. The top layer (WSD) contains only strong calcite peaks.

Well-formed crystals that are separated from the fracture surface of repair plaster are analyzed by XRD and FTIR. The XRD pattern in Fig. 1 is a perfect match for ettringite (ICDD 37-1476). In its FTIR spectrum, major vibrational bands corresponding to $\mathrm{OH}$ stretching $\left(3643 \mathrm{~cm}^{-1}\right), \nu_{3} \mathrm{H}_{2} \mathrm{O}$ $\left(3433 \mathrm{~cm}^{-1}\right), \nu_{2} \mathrm{H}_{2} \mathrm{O}\left(1676 \mathrm{~cm}^{-1}\right), \mathrm{CO}_{3}\left(1429 \mathrm{~cm}^{-1}\right), \nu_{3}$ $\mathrm{SO}_{4}\left(1120 \mathrm{~cm}^{-1}\right), \mathrm{Al}-\mathrm{O}-\mathrm{H}$ bending vibration $(863-626$ $\left.\mathrm{cm}^{-1}\right), \mathrm{AlO}_{6}\left(544 \mathrm{~cm}^{-1}\right)$, and $\nu_{2} \mathrm{SO}_{4}\left(420 \mathrm{~cm}^{-1}\right)$ are observed (Fig. 2).

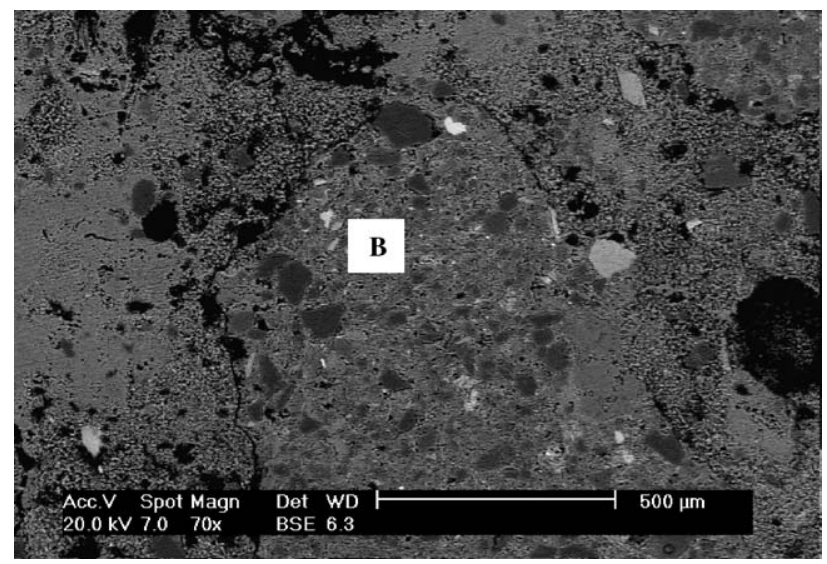

Fig. 4. Backscattered electron image (BSE) of brick aggregate (B) in polished sample type 1-b.

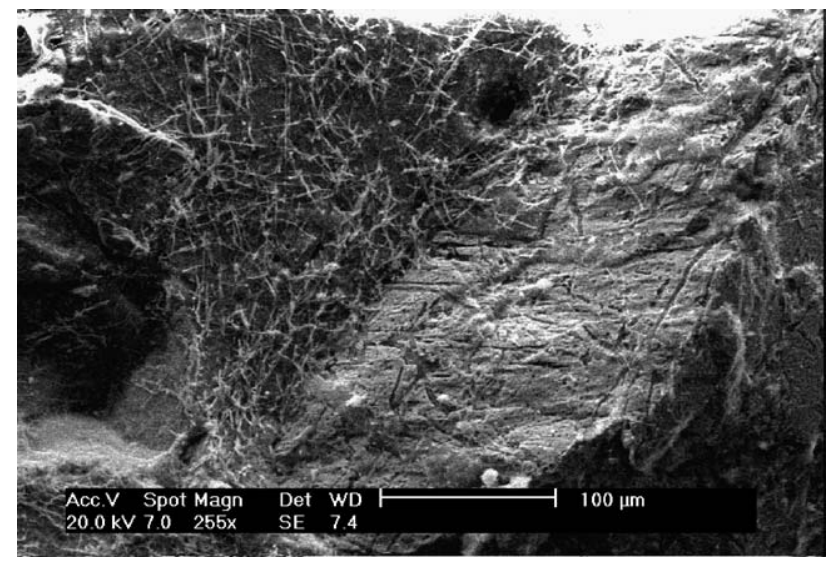

Fig. 5. Secondary electron image of needle-like crystals in type 2 sample.

\subsection{Microstructural analysis}

General microstructural observations are performed by both secondary electron image (SEI) and BSE (backscattered electron image) coupled with EDS to identify the microstructural features.

Fig. 3 shows that type 1-t is a structurally sound plaster with considerably less porosity than the bottom layer (type $1-b)$. The cohesion between the top and bottom layers is diffuse and strong.

BSE micrograph of type 1-b is shown in Fig. 4. A large brick fragment $(\sim 600 \mu \mathrm{m})$ is clearly visible in the middle of the picture. The internal details of the brick fragment indicated the presence of dispersed filler grains of feldspar and quartz. Brick-binder interface is generally free from pores and cracks.

The internal structure of the brick particle from type 2 plaster shows the presence of needlelike calcium aluminum hydrate and calcium silicate hydrate crystals (Fig. 5) as confirmed by EDS (Fig. 6).

Long fibrils of ettringite crystals that grew in type 2 are observed in optical microscope and SEM. The SEM micrograph and EDS analysis of the crystals are shown in Figs. 7 and 8, respectively. Relatively high concentrations of $\mathrm{Ca}$, $\mathrm{Al}$, and $\mathrm{S}$ are detected in all crystals.

Large calcite crystals in the white surface deposits (WSD) are observed in SEM (Fig. 9), and their EDS analysis showed a high amount of calcium (Fig. 10).

\section{Discussion}

The plaster samples investigated in this study were used in a historic bath. The fact that calcite is identified in the top layers of all samples (Table 2) confirms this. Historic bath plasters are designed to operate under high humidity and warm conditions. 


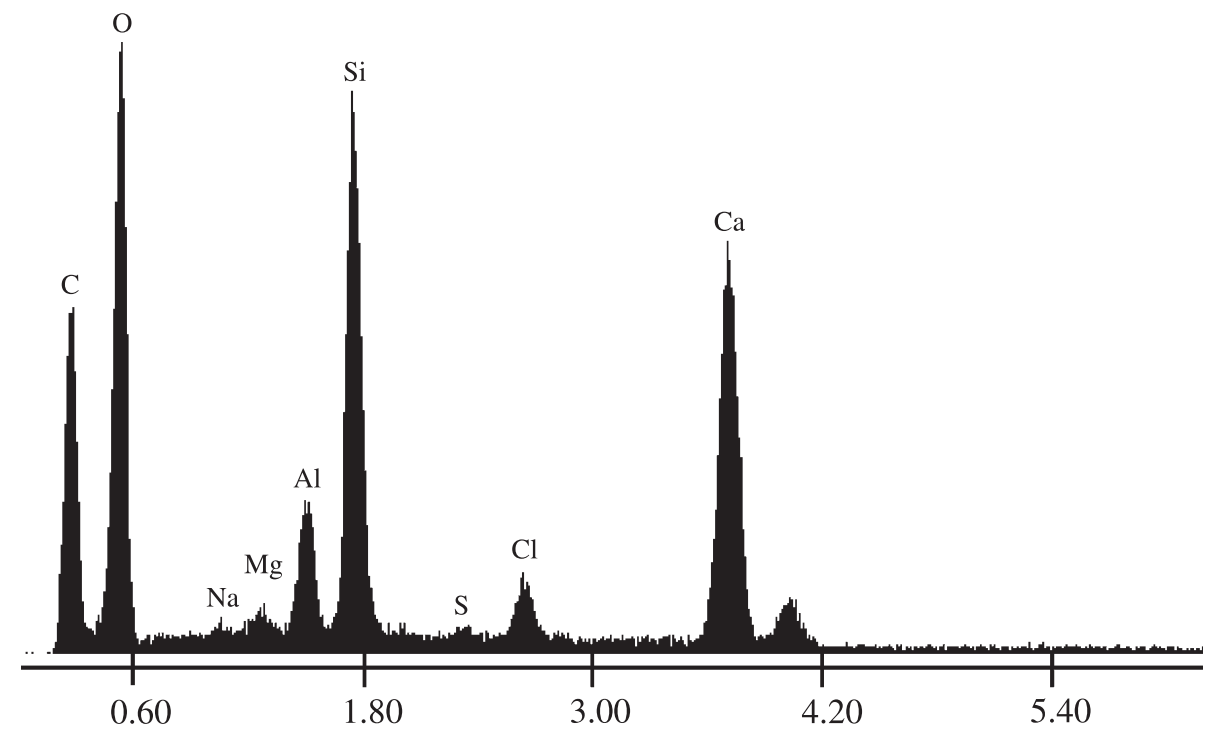

Fig. 6. EDS analyses of the needle-like calcium aluminum silicate hydrate crystals in type 2 sample in Fig. 5.

On-site observations of the plaster samples indicated that a significant portion of the bath wall plasters remained in perfectly good condition without the loss of strength (type 1). Other locations in the same wall where repair work appeared to be conducted showed extensive cracks and spalls (type 2).

Both plaster samples analyzed for their brick powder contents, size distributions, and their pozzolanacity showed no significant differences (Table 1). Pozzolanic activity measurements are carried out on the fine fraction of the powder $(<45 \mu \mathrm{m})$. The results as shown in Table 1 indicates that the fine aggregates have the pozzolanic activity values well over $1.2 \mathrm{mS} / \mathrm{cm}$ above which is accepted as good pozzolanacity [16]. Therefore, deterioration of type 2 plaster cannot result from differences in the

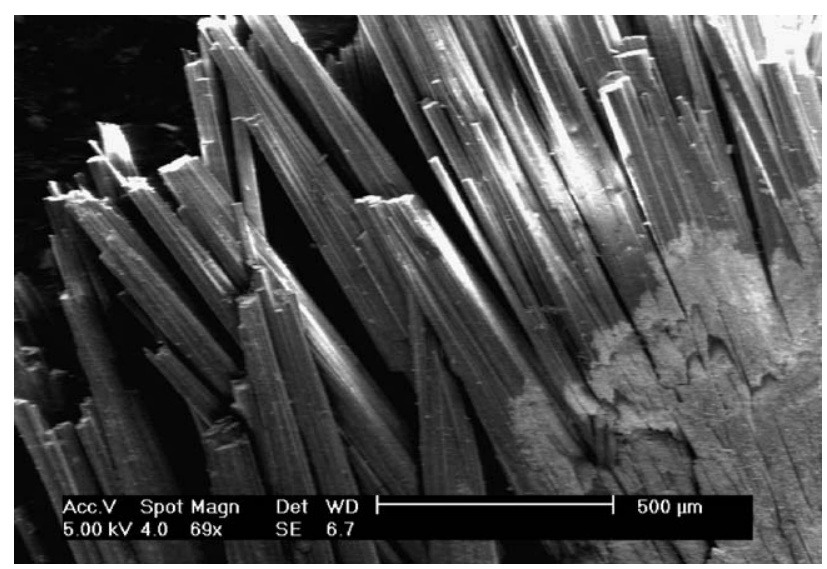

Fig. 7. Secondary electron image (SE) of fibrillar ettringite crystals in type 2 sample and their EDS analyses. amount of brick powder, their pozzolanacity, and lime contents.

Elongated crystals are detected in Type 2 samples in stereomicroscope. Analysis of these crystals by XRD and FTIR showed that they are ettringite (Figs. 1 and 2). The SEM-EDS examination also confirms these findings. There is $44.7 \% \mathrm{CaO}, 19.4 \% \mathrm{Al}_{2} \mathrm{O}_{3}$, and $35.9 \% \mathrm{SO}_{3}$ in these crystals (Table 3 ). This is very close to the ideal stoichiometric composition of $49.6 \% \mathrm{CaO}, 15.0 \% \mathrm{Al}_{2} \mathrm{O}_{3}$, and $35.4 \% \mathrm{SO}_{3}$ for ettringite (Table 3). The cracks and spalls observed in type 2 plaster is attributed to the expansion forces generated by the formation of ettringite crystals.

Amorphous phase is observed in samples containing calcined clay, that is a product of the destruction of crystal structure upon heating. The diffuse band with a slight increase in intensity on X-ray spectra between $20-30^{\circ} 2 \theta$ is characteristic of such materials. The brick powder particles possibly contain pozzolanic metakaolin as the dissociation product of kaolinite upon heating up to $500-600{ }^{\circ} \mathrm{C}$ (Eq. (1)). The remnants of metakaolin in brick appear to have reacted with lime to form calcium aluminum hydrate and calcium silicate hydrate as suggested by EDS analysis (Figs. 5-6). Fine interconnected network of needlelike hydration products also suggest this mechanism.

The pozzolanic metakaolin derived from the kaolinite in brick powder reacts with lime and water to form $4 \mathrm{CaO} \cdot \mathrm{Al}_{2} \mathrm{O}_{3} \cdot 19 \mathrm{H}_{2} \mathrm{O}$, which further reacts with gypsum in a moist environment to form ettringite (Eqs. (1-3) [11]. Such environments are often experienced in historic baths.

$$
\underset{\text { Kaolinite }}{\mathrm{Al}_{2} \mathrm{O}_{3} \cdot 2 \mathrm{SiO}_{2} \cdot 2 \mathrm{H}_{2} \mathrm{O}} \underset{\text { Metakaolin }}{\rightarrow \mathrm{Al}_{2} \mathrm{O}_{3} \cdot 2 \mathrm{SiO}_{2}}+\underset{\text { Water }}{2 \mathrm{H}_{2} \mathrm{O}}
$$




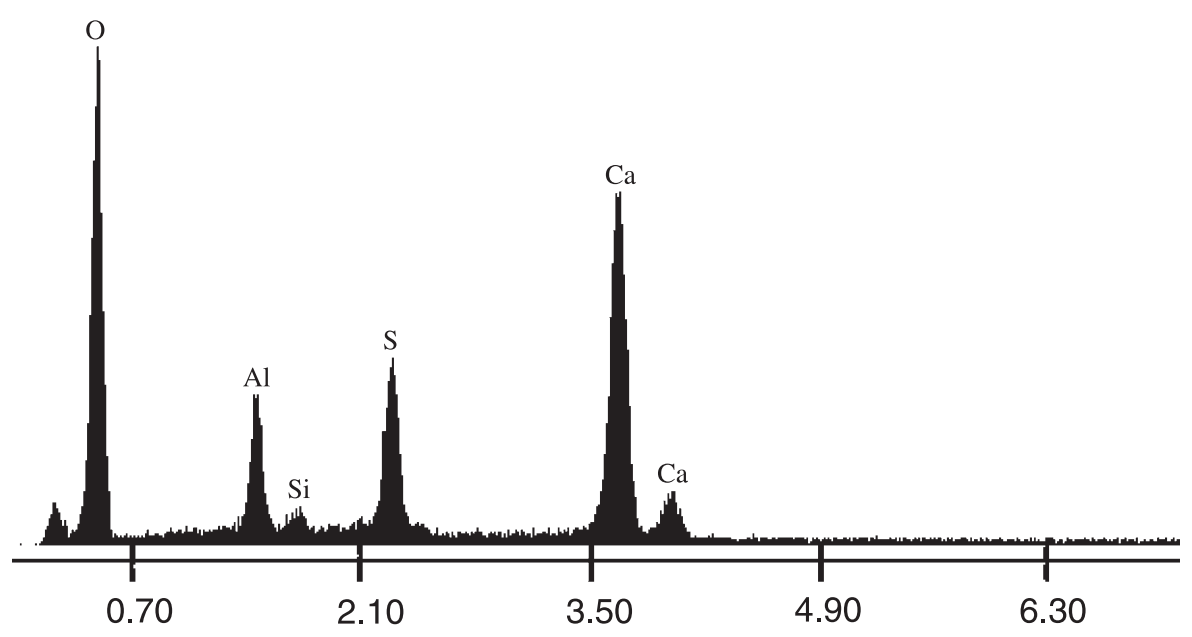

Fig. 8. EDS analyses of the ettringite crystals in type 2 sample in Fig. 7.

When metakaolin, lime, and water are combined, depending on the conditions, different phases may form. Prince et al. [17] reported that "when the basic mixture is mixed and maintained at ambient temperature, lime solubility is high. There is an abundance of calcium ions in the interstitial liquid, and the $\mathrm{pH}$ is greater than 12.5 because of the presence of some alkali brought by metakaolin. Under these conditions silica and alumina go into solution more or less rapidly reacting to yield two distinct hydration products: tetracalcium aluminate hydrate $\left(4 \mathrm{CaO} \cdot \mathrm{Al}_{2} \mathrm{O}_{3} \cdot 19 \mathrm{H}_{2} \mathrm{O}\right)$ and calcium silicate hydrate $(\mathrm{CSH})$. Both are precipitated as soon as saturation levels are reached. The aluminate is clearly crystallized, while the silicate is much less so." This is represented by Eq. (2) [17]:

$$
\begin{aligned}
& \mathrm{Al}_{2} \mathrm{O}_{3} \cdot 2 \mathrm{SiO}_{2}+7 \mathrm{Ca}(\mathrm{OH})_{2} \\
& \begin{array}{l}
\text { Metakaolin } \\
\mathrm{Lime}
\end{array} \\
& \rightarrow 4 \mathrm{CaO} \cdot \mathrm{Al}_{2} \mathrm{O}_{3} \cdot 19 \mathrm{H}_{2} \mathrm{O}+3 \mathrm{CaO} \cdot 2 \mathrm{SiO}_{2} \cdot 7 \mathrm{H}_{2} \mathrm{O} \\
& \mathrm{CSH}
\end{aligned}
$$

When the plasters produced according to Eq. (2) are subjected to high-humidity environments, the plaster

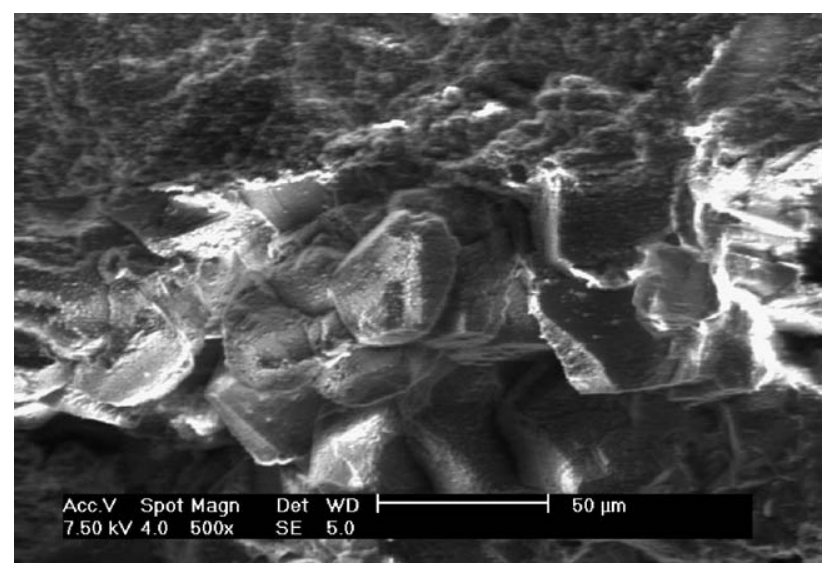

Fig. 9. Secondary electron image of deposited calcite layer (WSD) on the top layer of sample type 2 . becomes more stable, making these materials ideal for bath use. In case the plaster contains gypsum, however, a reaction may occur as shown in Eq. (3) to produce ettringite that leads to deterioration of plaster.

$$
\begin{gathered}
4 \mathrm{CaO} \cdot \mathrm{Al}_{2} \mathrm{O}_{3} \cdot 19 \mathrm{H}_{2} \mathrm{O}+\underset{\text { Gypsum }}{2 \mathrm{CaSO}_{4} \cdot 2 \mathrm{H}_{2} \mathrm{O}}+11 \mathrm{H}_{2} \mathrm{O} \\
\rightarrow 3 \mathrm{CaO} \cdot \mathrm{Al}_{2} \mathrm{O}_{3} \cdot 3 \mathrm{CaSO}_{4} \cdot 32 \mathrm{H}_{2} \mathrm{O} \\
\text { Ettringite }
\end{gathered}
$$

As we can see from Eq. (3), a source of gypsum is necessary for the formation of ettringite from calcium aluminum hydrates. This gypsum can be provided by air pollution, portland cement application, rising damp from soil or gypsum addition during the preparation of the plaster.

XRD analyses on powder samples and EDS on bulk samples in SEM of the calcite layer deposited on the surfaces of all plaster samples (WSD) did not show the presence of gypsum (Fig. 10 and Table 2). This suggests that air pollution cannot provide the gypsum source for the formation of ettringite. Otherwise, ettringite must have formed in both types of plasters.

There was no Portland cement application on the wall to provide gypsum for ettringite formation. Capillary rising water from the foundation may not have contributed gypsum either. If that had been the case, the type 1 plaster should have been affected by ettringite formation too.

The most likely source for gypsum appears to be its addition during the preparation of plasters to attain early strength [5-7]. The gypsum, in accordance with Eq. (3), probably reacts with the $4 \mathrm{CaO} \cdot \mathrm{Al}_{2} \mathrm{O}_{3} \cdot 19 \mathrm{H}_{2} \mathrm{O}$ to form ettringite. This reaction requires relatively high humidity often found in baths. SEM-EDS analyses of the cross-section of the samples away from the identified ettringite crystals did not show the presence of measurable amounts of sulfur in the samples. This may be the result of the consumption of all gypsum for the formation of ettringite in accordance with Eq. (3). 


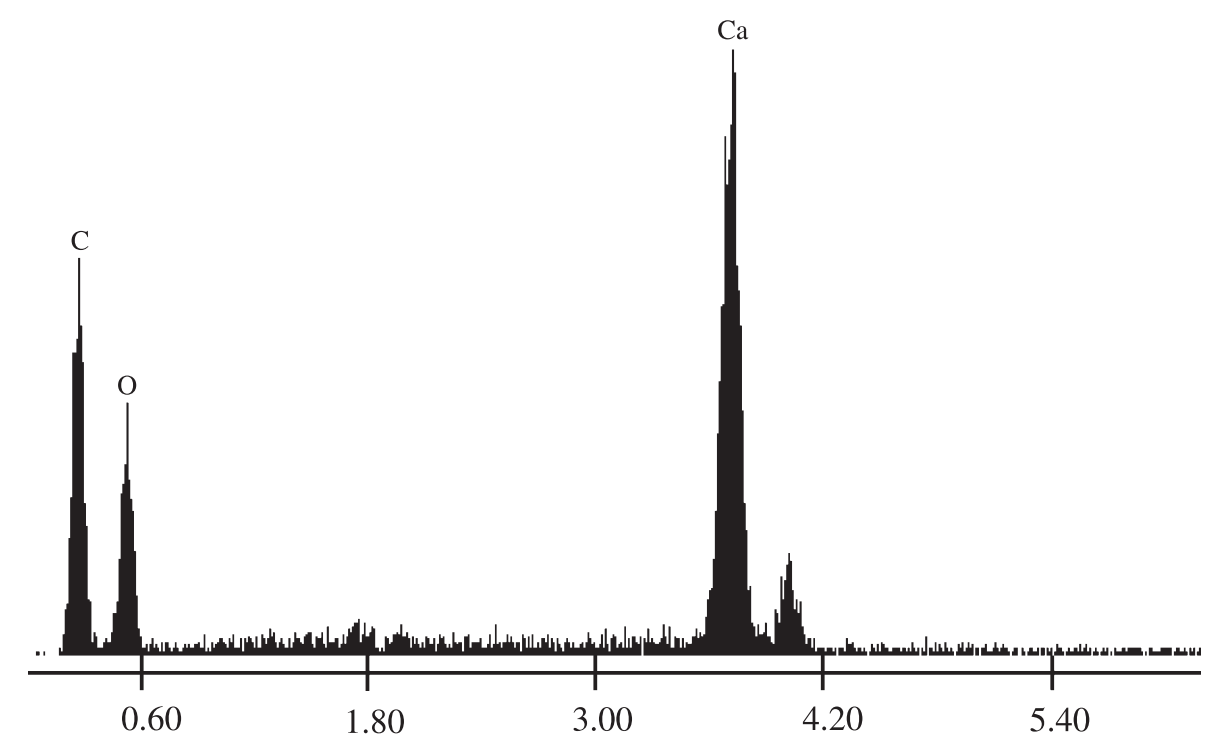

Fig. 10. EDS analyses of the deposited calcite layer (WSD) on the top layer of sample type 2 in Fig. 9.

According to historical records, the building was subjected to repair work in 1565 and sometime in the 18th century [14]. Therefore, the ettringite crystals in the historic repair plaster grew either after 1565 or after the 18 th century.

\section{Conclusions}

An original and a historic repair plaster sample are taken from a historic bath wall. The former is physically strong and sound, and the latter has lost its strength and adhesion. Welldefined fibrillar crystals of ettringite are observed in the repair samples, not the original one. The reason for deterioration of the repair plaster may be attributed to the growth of ettringite crystals and the resulting expansion forces.

It is known that gypsum has been used in historic mortars and plasters as an additive. When such structures are exposed to humid conditions such as rising damp and rain penetration, the sulfate already present in gypsum brings about ettringite formation. Therefore, such buildings to which gypsum has already been added should be protected from moisture to avoid ettringite formation.

Table 3

Composition of ettringite crystals observed in this study and that of ideal stoichiometric crystals

\begin{tabular}{lll}
\hline Oxide & $\begin{array}{l}\text { EDS analysis of } \\
\text { observed ettringite } \\
\text { crystals, weight } \\
\text { percent }\end{array}$ & $\begin{array}{l}\text { Ideal stoichiometric } \\
\text { ettringite weight } \\
\text { percent }\end{array}$ \\
\hline $\mathrm{CaO}$ & 44.7 & 49.6 \\
$\mathrm{Al}_{2} \mathrm{O}_{3}$ & 19.4 & 15.0 \\
$\mathrm{SO}_{3}$ & 35.9 & 35.4 \\
\hline
\end{tabular}

Use of gypsum as an early strength-developing aid in hydraulic lime plasters or mortars should be avoided.

\section{Acknowledgements}

This work was supported by the research grants of ICTAG-I674 (TUBİTAK) and DPT 2002 K120390. The authors thank Duygu Oğuz and Gökhan Erdoğan for XRD and SEM-EDS analysis during the experimental stage of this work.

\section{References}

[1] A. Güleç, T. Tulun, Physico-chemical and petrographical studies of old mortars and plasters of Anatolia, Cem. Concr. Res. 27 (2) (1997) $227-234$

[2] R. Spence, Lime and surkhi manufacture in India, Appropr. Technol. 1 (4) (1974) 6-8.

[3] F.M. Lea, Investigations on pozzolanas, Building Research, Technical Paper No. 27 (1940) 1-63.

[4] F. Massazza, M. Pezzuoli, Some teachings of a Roman concrete mortars, in Mortars, Cement and Grouts Used in the Conservation of Historic Buildings, ICCROM, Rome, 1981, pp. 219-245.

[5] H. Jedrzejevska, Ancient mortars as criterion in analysis of old architecture, in Mortars, Cements and Grouts Used in the Conversation of Historic Buildings, ICCROM, Rome, 1981, pp. 311-329.

[6] A. Moropoulou, A. Bakolas, K. Bisbikou, Characterization of ancient Byzantine and later historic mortars by thermal and X-ray diffraction techniques, Thermochim. Acta 269/270 (1995) 779-795.

[7] M.P. Riccardi, P. Duminuco, C. Tomasi, P. Ferloni, Thermal, microscopic and X-ray diffraction studies on some ancient mortars, Thermochim. Acta 321 (1998) 207-214.

[8] J. Ambroise, M. Murat, J. Pera, Hydration reaction and hardening of calcined clays and related minerals: V. Extension of the research and general conclusions, Cem. Concr. Res. 15 (1985) 261-268.

[9] C. He, B. Osbaeck, E. Makavicky, Pozzolanic reactions of six princi- 
pal clay minerals: activation, reactivity assessments and technological effects, Cem. Concr. Res. 25 (8) (1995) 1691-1702.

[10] C. Shi, L.R. Day, Acceleration of strength gain of lime-pozzolan cements by thermal activation, Cem. Concr. Res. 23 (1993) 824-832.

[11] M. Collepardi, Thaumasite formation and deterioration in historic buildings, Cem. Concr. Comp. 21 (1999) 147-154.

[12] C. Sabbioni, G. Zappia, C. Riontino, M.T. Blanco-Varela, J. Aguilera, F. Puertas, K.V. Balen, E.E. Toumbakari, Atmospheric deterioration of ancient and modern hydraulic mortars, Atmos. Environ. 35 (2001) $539-548$.

[13] C. Sabbioni, A. Bonazza, G. Zappia, Damage on hydraulic mortars: the Venice arsenal, J. Cult. Heritage 3 (2002) 83-88.
[14] G. Vanli, Restoration project of the Saray Bath in Edirne. Master's thesis, METU Library (1993) 232.

[15] H. Jedrzejevska, Ancient mortars as criterion in analysis of old architecture, Proceedings of Symposium on Mortars, Cements and Grouts used in the Conservation of Historic Buildings, Rome, 1981, pp. 311-329.

[16] M.P. Luxan, F. Madruga, J. Saavedra, Rapid evaluation of pozzolanic activity of natural products by conductivity measurements, Cem. Concr. Res. 19 (1989) 63-68.

[17] W. Prince, G. Castanier, J.L. Giafferi, Similarity between alkali-aggregate reaction and the natural alteration of rocks, Cem. Concr. Res. 31 (2001) 271-276. 